\title{
Some Aspects of the Quality of Corporate Governance in Digital Economy
}

\author{
A.A. Polidi ${ }^{1}$, Z.O. Goukasyan ${ }^{1}$, I.A. Maslova ${ }^{1}$ and R.V. Fedorenko ${ }^{2, *}$ \\ *Corresponding author: rammy@list.ru \\ ${ }^{1}$ Orel State University, Orel, Russia \\ ${ }^{2}$ Samara State University of Economics, Samara, Russia
}

\begin{abstract}
The relevance of this article is due to technological changes that are constantly introducing new characteristics, both in the global economic system and in the economy of individual fields of activity. The newest digital economy is significantly different from the traditional economy. A modern business environment requires constant adaptation of an entrepreneur to dynamically changing conditions at a strategic and tactical level.

The purpose of the article is to study aspects of the quality of corporate governance, taking into account the challenges of the digital economy.

The objectives of the study are: to identify the key elements of corporate governance and environmental factors affecting them; to determine the conditions and factors of the formation of economic interests in the corporate governance system for the purpose of improving the quality of corporate governance in the digital economy.
\end{abstract}

Keywords: corporate governance, balance of interests, quality, assessment, business entities, digital economy.

\section{Introduction}

Modern globalization, growth and competitiveness of the national economy, geopolitical and geo-economic factors determine the level of intellectualization of the main factors of production. The consequence of these factors is the continuous development of digital technology. Currently corporations are the main participants in domestic and foreign economic policy. In modern conditions, corporations have a growing influence on the development of the country's digital economy. This necessitates the study of issues of ownership, its structure and the impact on corporate governance in a digitalizing economy. The article discusses the process of corporate governance and its elements. The management model in a particular organization depends on the choice of shareholders and their fragmentation, the number of stakeholders, the degree of independence of the governing bodies, the model of interaction between owners and top management. The quality of management depends on the degree of development of tools and mechanisms for resolving conflicts of corporate entities, striving to ensure a balance of interests. The article is aimed at assessing the quality of management in the conditions of digitalization of the economy.

\section{Problem Statement}

In modern science, the attention of scientists focuses not only on solving tactical problems of the state's economic development, but also on developing and justifying strategic actions, including the development of the digital economy and corporate governance.

The digital economy began its existence in 1994, when the Virtual Economic System was described in the book "Digital Economy" by Don Tapscott. Subsequently, he continued research on this topic [1, 2]. In 1995, N. Neogronte formulated the basic principles of the digital economy [3].

The works of A.P. Dobrynin et al. are devoted to the issues of digitalization and virtual technologies, including those providing the process of corporate governance [4]. M.A. Averyanov et al. [5], S. Baller et al. [6], G. Dosi [7] investigated the problems of corporate governance development in the digital economy era.

A great contribution to the development of the theory of corporate governance was made by K. Meyer et al. [8], O.E. Williamson [9], K.A. Birch [10], and others. Z.O. Gukasyan et al. [11, 12], A.D. Zaretsky \& T.Ye. Ivanova [13], A. Frolov \& I. Maslova [14] engaged in the study of the formation and development of corporate governance, quality assessment, social responsibility and innovative value. R. Kapelyushnikov \& N. Demina [15], A.N. Oleinik [16] and other scientists studied the problems of the structure of joint stock ownership and their impact on corporate governance. 


\section{Research Questions}

Many researchers have been studying the presented problem. However, so far neither in a scientific society, nor in practical application there is no clearly built and logically structured solution to the issue of assessing the quality of corporate governance and ensuring the economic interests of corporate entities in the digital economy.

The study of world practice, features and trends in the development of the digital economy and corporate governance allows us to develop the country's potential, create conditions for economic growth and promote the improvement of national welfare.

\section{Purpose of the Study}

The emergence of new digital infrastructures, the development of computer technology and digital communications create new opportunities in the field of information technology. All this forms a new system of the digital economy. Russia seeks the status of an innovative state. The country is facing a new technological challenge that can significantly change the system of organization and management of economic processes. All these factors have a profound impact on the corporate governance system in terms of developing new approaches to the quality of corporate governance. The purpose of the article is to study aspects of the quality of corporate governance, taking into account the challenges of the digital economy.

\section{Research Methods}

The theoretical and methodological basis of the study consists of the fundamental principles of the theory of digital economics and management, conceptual foundations of the corporate, scientific research results of foreign and Russian scientists on the problems of corporate management and assessment of its quality, as well as institutional decisions of the state in this area. The use of an integrated and systematic approach in the process of researching the patterns and characteristics of corporate governance development in Russia makes it possible to obtain the desired results. The methods of structural-functional research and comparative analysis allow us to identify existing approaches to assessing the quality of corporate governance elements that are important in the context of the development of the digital economy. The results of the study are presented using a graphical visualization method.

\section{Findings}

Corporate governance essentially includes a set of subjects (owners, managers, personnel), a model of government regulation, tools and mechanisms for innovative development and achieving a balance of economic interests, principles of fairness, responsibility, accountability and transparency, as well as a set of corporate management tools.

Key elements of corporate governance and environmental factors affecting them are presented in Figure 1.

The quality of corporate governance represents the degree of compliance of the actions of the management system with the interests (economic, environmental and social) of the owners, employees of the company, the state and society as a whole. All this are dynamically changing under the influence of internal and external factors.

In an innovative economy, corporations implement strategies and tactics that allow them to adapt their economic interests. As a result, in a financial crisis, two scenarios often arise that are directly related to the quality of corporate governance (Figure 2).

New tools of the digital economy can improve the quality of corporate governance by replacing outdated regulatory models. Instead of reports, checks, statements, etc. modern digital platforms use algorithmic regulation of the activities to estimate all elements of the corporate governance system. This reduces the subjectivity of the internal assessment of the quality of corporate governance.

The state program "Digital Economy of the Russian Federation" presents two main indicators in the aspect of corporate governance [17]. First indicator represents growth of the economy and increase of its competitiveness through the creation of a sustainable and secure information and telecommunications infrastructure. Second indicator shows introduction of advanced digital technologies and platform solutions in Russian companies. 
External and internal digital environment

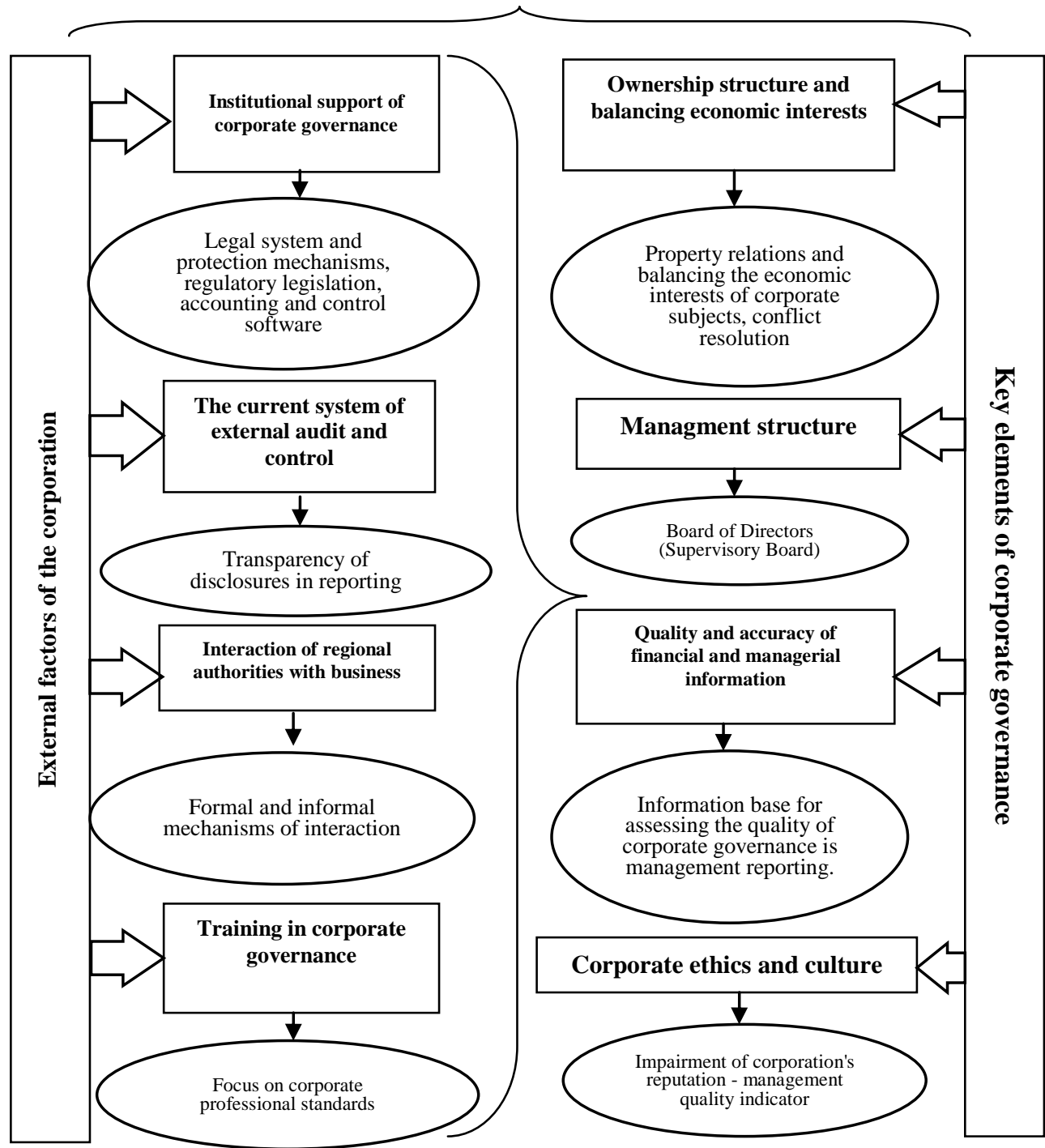

Figure 1. Key elements of corporate governance

(Source: compiled by the authors) 

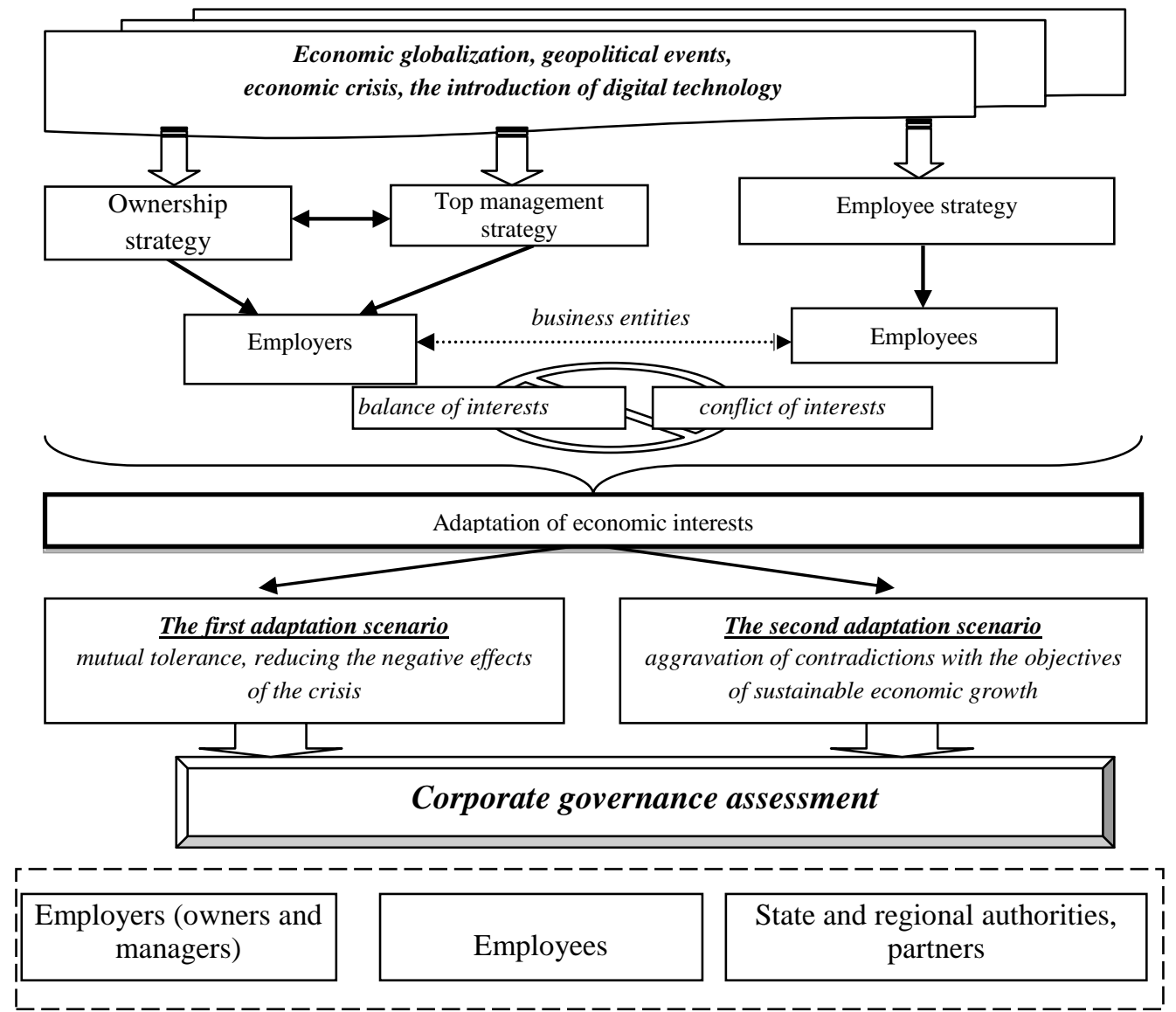

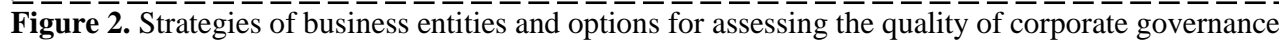
(Source: compiled by the authors)

Thus, by 2024, it is planned to achieve the "GDP growth due to the development of the digital economy" up to $1.1 \%$, and the share of companies using informatization and business process automation systems - up to 38\%. Large companies are introducing the concept of a virtual office, especially for remote divisions. At the same time, the widespread use of the Internet of Things and production automation is actively developing. Table 1 shows the forecast values of these indicators for 2018-2024.

Table 1. Forecasted values of digital economy in the aspect of corporate development, $\%$

\begin{tabular}{|l|l|l|l|l|l|l|l|}
\hline \multicolumn{2}{|c|}{ Goal } & \multicolumn{7}{c|}{ Period, year } \\
\cline { 2 - 9 } & 2018 & 2019 & 2020 & 2021 & 2022 & 2023 & 2024 \\
\hline $\begin{array}{l}\text { Annual growth of gross domestic } \\
\text { product due to the development of the } \\
\text { digital economy without taking into } \\
\text { account other factors }\end{array}$ & - & 0,3 & 0,5 & 0,7 & 0,9 & 1 & 1,1 \\
\hline $\begin{array}{l}\text { Percentage of organizations using } \\
\text { informatization and business process } \\
\text { automation systems (CRM, ERP, SCM } \\
\text { systems) in the total number of } \\
\text { organizations }\end{array}$ & 17 & 20 & 24 & 28 & 32 & 35 & 38 \\
\hline
\end{tabular}

Source: compiled by the authors on the basis of [17]

Large corporations successfully use modern digital tools in production cycle control systems. A number of them can also be used to assess the degree of balance of interests of the subjects of corporate governance, the contribution of each entity to the improvement of the quality of the corporate governance system, and the contribution of each participant to the system of increasing productivity. In particular, we are talking about the concept of "digital twin". Currently, these digital models are customer-oriented, which means they are directed outside the corporation. However, building digital model data for assessing the quality of internal corporate governance also has great potential. 


\section{Conclusion}

Thus, the article examines the main aspects of the quality of corporate governance in the conditions of the formation of the digital economy at the stage of the birth of a new technological order. Currently, judging by the official statistics, only a limited number of organizations use integrated management automation systems. The use of information technology in corporate governance is currently focused on core activities, as well as on managing relations with external counterparties. However, to assess the level of quality of corporate governance, it is necessary to build management based on a balance of interests, as well as to lay performance indicators in corporate management information systems in order to objectively research them and improve the quality of corporate management.

\section{Acknowledgments}

The article was prepared while carrying out research work in the framework of the project part of the state task in the field of scientific activity in accordance with task No. 26.2758.2017 / 4.6 for 2017-2019.

\section{References}

1. D. Tapscott, The digital economy: Promise and peril in the age of networked intelligence. New York, NY: McGrawHill (1995).

2. D. Tapscott, Digital society: The pros and cons of the era of network intelligence. Kiev: 1NT Press (1999).

3. N. Neogronte, Being digital. New York, NY: Knopf (1995).

4. A.P. Dobrynin, K.Yu. Chernykh, V.P. Kupriyanovskiy, P.V. Kupriyanovskiy, S.A. Sinyagov, Digital economy various ways to effectively apply technologies (BIM, PLM, CAD, IOT, Smart City, BIG DATA and others). International Journal of Open Information Technologies, 4(1), 4-11 (2016). [in Rus.].

5. M.A. Averyanov, S.N. Evtushenko, E.Yu. Kochetkova, Digital society: New challenges. Economic Strategies, 7(141), 90-91 (2016). [in Rus.].

6. S. Baller, S. Dutta, B. Lanvin, (Eds.) The global information technology report 2016: Innovating in the digital economy. URL: http://www3.weforum.org/docs/GITR2016/WEF_GITR_Full_Report.pdf. Accessed: 26.11.2018 (2016).

7. G. Dosi, Technological paradigms and technological trajectories: A suggested interpretation of the determinants and directions of technical change. Research Policy, 11(3), 147-162. URL: https://ssrn.com/abstract=1505191 (1982).

8. K. Meyer, M. Hessel, D. Lorsch, Corporate governance: owners, directors and employees of AO. Moscow: John Wiley and Sons (1996).

9. O.E. Williamson, The vertical integration of production: Market failure considerations. The American Economic Review, 61(2), Papers and Proceedings of the Eighty-Third Annual Meeting of the American Economic Association (May, 1971), 112-123 (1971).

10. K.A. Birch, Methods of assessing the level of corporate governance used by Moody's in conducting credit analysis. Journal “Joint-stock Company: Issues of Corporate Governance”, 8(27), 45-52 (2006). [in Rus.].

11.Z.O. Gukasyan, R.L. Agabekyan, G.L. Bayanduryan, Identification the quality of corporate governance concept. Quality - Access to Success, 19(164), 88-93 (2018).

12. Z.O. Gukasyan, Stages of transformation of shareholder ownership in Russia and the direction of its influence on the quality of corporate governance. Economic and Human Sciences, 10, 111-117 (2014). [in Rus].

13. A.D. Zaretsky, T.Ye. Ivanova, Corporate social responsibility. World and domestic practice. Krasnodar: KSEI (2012). [in Rus.].

14. A. Frolov, I. Maslova, Subject-independent modeling and representation data on the formation and distribution of innovative value. MATEC Web of Conferences, 132(04019), 1-5. DOI: 10.1051/matecconf/201713204019 (2017).

15. R. Kapelyushnikov, N. Demina, The influence of the characteristics of ownership on the results of economic activities of Russian industrial enterprises. Questions of Economics, 2, $53-68$ (2005). [in Rus].

16. A.N. Oleinik, Power and market. The system of socio-economic domination in Russia "zero years". Moscow: ROSSPEN (2011). [in Rus.].

17. Government of the Russian Federation, The program "Digital Economy of the Russian Federation" Approved. Decree of the Government of the Russian Federation 28.07.2017 N 1632-p. Retrieved from: http://static.government.ru/media/files/9gFM4FHj4PsB79I5v7yLVuPgu4bvR7M0.pdf. Accessed: 22.11.2018 (2017). [in Rus.]. 